\title{
Decline of mortality from cervical cancer
}

\author{
Declínio da mortalidade por câncer cervical \\ Disminución de la mortalidad por cáncer cervical
}

\section{Suelayne Gonçalves do Nascimento', Cleonice Patrícia Andrade Lima de Carvalho", Ricarlly Soares da Silva"', Conceição Maria de Oliveira' ${ }^{\mathrm{IV}}$, Cristine Vieira do Bonfim ${ }^{\text {v }}$}

' Hospital e Maternidade Petronila Campos, Department of Nursing. São Lourenço da Mata, Pernambuco, Brazil.

"Centro Universitário Maurício de Nassau, Postgraduate Program in Nursing. Recife, Pernambuco, Brazil.

II' State Secretariat of Health of Pernambuco, Department of Health Surveillance. Recife, Pernambuco, Brazil.

${ }^{\prime V}$ Centro Universitário Maurício de Nassau, Health Department. Recife, Pernambuco, Brazil.

${ }^{v}$ Universidade Federal de Pernambuco, Postgraduate Program in Public Health. Recife, Pernambuco, Brazil.

How to cite this article:

Nascimento SG, Carvalho CPAL, Silva RS, Oliveira CM, Bonfim CV. Decline of mortality from cervical cancer.

Rev Bras Enferm [Internet]. 2018;71(Suppl 1):585-90. [Thematic Issue: Contributions and challenges of nursing practices in collective health] DOI: http://dx.doi.org/10.1590/0034-7167-2016-0530

Submission: 09-11-2016 Approval: 09-07-2017

\section{ABSTRACT}

Objective: To describe occurrences of mortality due to cervical cancer in Recife (PE), in northeastern Brazil. Method: This was a time-series ecological study using data from the Mortality Information System (SIM) regarding the total number of deaths due to cervical cancer (C53 ICD10) that occurred between 2000 and 2012. Results: It was observed that the risk of death due to this form of cancer was higher among women over 60 years of age, those of mixed skin color $(53.24 \%$ ), those who only worked at home $(63.16 \%)$ and those who did not have a partner (44.32\%). Conclusion: Additional efforts towards maintaining early detection and health education programs and towards using therapeutic strategies of greater efficiency are needed, given that mortality due to this form of cancer is considered avoidable when diagnosed early.

Descriptors: Uterine Cervical Neoplasms; Mortality; Information Systems; Oncology Nursing; Vital Statistics.

\section{RESUMO}

Objetivo: Descrever a ocorrência da mortalidade por câncer no colo uterino no Recife (PE), região nordeste do Brasil. Métodos: Estudo ecológico de série temporal com dados do Sistema de Informações sobre Mortalidade (SIM), referente ao total de óbitos por câncer no colo uterino (C53 - CID10), ocorridos no período de 2000 a 2012. Resultados: Observou-se que o risco de morte por esta neoplasia cresce em mulheres a partir dos 60 anos, pardas $(53,24 \%)$, donas de casa $(63,16 \%)$ e sem companheiros $(44,32 \%)$. Conclusão: É necessário esforço adicional através da manutenção de programas de detecção precoce, educação em saúde e uso de estratégias terapêuticas mais eficientes, pois a mortalidade por essa neoplasia é considerada evitável quando diagnosticada precocemente.

Descritores: Câncer do colo do útero; Mortalidade; Sistemas de Informação; Enfermagem Oncológica; Estatísticas Vitais.

\section{RESUMEN}

Objetivo: Describir la ocurrencia de mortalidad por cáncer cervical en Recife (PE), en el noreste de Brasil. Método: Este fue un estudio ecológico de series temporales que utilizó datos del Sistema de Información de Mortalidad (SIM) sobre el número total de muertes por cáncer cervical (C53 ICD10) ocurridas entre 2000 y 2012. Resultados: Se observó que el riesgo de muerte por esta forma de cáncer fue mayor entre las mujeres mayores de 60 años, las de color de piel mixto (53.24\%), las que sólo trabajaban en casa $(63.16 \%)$ y las que no tenían pareja (44.32\%). Conclusión: Se requieren esfuerzos adicionales para mantener los programas de detección precoz y educación sanitaria y para utilizar estrategias terapéuticas de mayor eficacia, ya que la mortalidad por esta forma de cáncer se considera evitable cuando se diagnostica tempranamente.

Descriptores: Neoplasias del Cuello Uterino; Mortalidad; Sistemas de Información; Enfermería Oncológica; Estadísticas Vitales.

\section{CORRESPNDING AUTHOR Cristine Vieira do Bonfim E-mail: cristine.bonfim@uol.com.br}




\section{INTRODUCTION}

Cancer is the leading cause of morbidity and mortality worldwide. According to the International Agency for Research on Cancer (IARC) in 2012, 14 million new cases and eight million deaths were reported, out of which $60 \%$ happened in Africa, Asia, Central and South America ${ }^{(1)}$. Among women, cervical cancer is the second most common and the third leading cause of death ${ }^{(2)}$. It is estimated at more than 270,000 the number of deaths from this cancer and over $85 \%$ of them are concentrated in developing countries ${ }^{(1)}$.

In Brazil, this neoplasia is the fourth most common type $^{(3)}$. In 2012, 5,264 deaths from this cancer were registered, of these, $1,678(31.87 \%)$ in the Northeast. In the state of Pernambuco, 277 deaths were registered, of which 57 $(20.57 \%)$ were residents in the city of Recife ${ }^{(4)}$. For the year 2015, 15,000 new cases of cervical cancer were estimated in the country ${ }^{(3)}$.

Infection by oncogenic types of Human Papilloma Virus (HPV) is the leading cause of cancer in the cervix ${ }^{(5-6)}$. Types 16 and 18 are responsible for $70 \%$ of invasive cervical cancers ${ }^{(7)}$. Although HPV infection is a necessary cause for the occurrence of this cancer, it is not enough for it to develop. Persistent infections with this virus cause more than 500,000 cases of invasive cervical cancer worldwide every year ${ }^{(8)}$.

Decreases in incidence and mortality rates observed in developed countries can be attributed to organized cytology screening programs ${ }^{(9-10)}$. The Pap smear is the primary screening strategy for cervical cancer recommended by the Department of Health in Brazil(11).

In spite of presenting a decrease in standardized mortality rates, this particular cancer still has a relevant role as a cause of death ${ }^{(12)}$. The mortality rate allows the analysis of the impact of prevention programs, access to health services, quality of diagnosis and treatment and women's adherence to screening programs. In Brazil, achieving lower mortality rates means to achieve effective tracking and increased survival.

\section{OBJECTIVE}

Describe the occurrence of death from cervical cancer in Recife (PE), in the northeast region of Brazil, from 2000 to 2012.

\section{METHOD}

\section{Ethical aspects}

The project was approved by the Research Ethics Committees (CEP) of Centro Universitário Maurício de Nassau. The study met national and international ethical guidelines for research involving human beings.

\section{Study design, site and period}

An ecological time-series study was conducted using data from the Mortality Information System (Sistema de Informações sobre Mortalidade, SIM) of the Brazilian Ministry of Health, state of Pernambuco, in the 2000-2012 period.

\section{Population, inclusion and exclusion criteria}

The study population consisted of all deaths caused by cervical cancer (ICD10, C53) among women living in Recife, state of Pernambuco, in the 2000-2012 period.

Based on the information obtained from SIM after being granted authorization to access the data, variables including age, race/color, marital status, and occupation were analyzed. The variable "level of education" was not analyzed because $55.1 \%$ of the records were blank or had been filled out as "not known".

\section{Study protocol}

The data used were provided by the Secretariat of Health of Recife, after the signing of a consent term by the general manager of Health Surveillance.

\section{Analysis of the results and statistics}

For data analysis, descriptive statistics, including the distribution of frequency (absolute and relative) and measures of central tendency, were performed using the programs Epilnfo version 7 and Statistical Package for the Social Sciences (SPSS) version 15 for Windows, in which the mortality rates were calculated (number of deaths by cervical cancer/female population x 100,000).

\section{RESULTS}

During the study period, there were 695 deaths from cervical cancer. The mortality rate declined from 7.62 in 2000 to $6.81 / 100,000$ women in 2012, representing a decrease of $10.62 \%$, and an average annual reduction of $0.89 \%$ (Table 1 ).

Table 1 - Number of deaths, female population, relative frequency and cervical cancer mortality rate (per 100,000)

\begin{tabular}{ccccc}
\hline Year & $\begin{array}{c}\text { Female } \\
\text { population }\end{array}$ & $\begin{array}{c}\text { No. of } \\
\text { deaths }\end{array}$ & $\%$ & $\begin{array}{c}\text { Coefficient of } \\
\text { mortality }\end{array}$ \\
\hline 2000 & 761,215 & 58 & 8.35 & 7.62 \\
2001 & 768,857 & 55 & 7.91 & 7.15 \\
2002 & 775,247 & 50 & 7.20 & 6.45 \\
2003 & 781,766 & 58 & 8.35 & 7.42 \\
2004 & 788,263 & 41 & 5.90 & 5.20 \\
2005 & 803,000 & 54 & 7.77 & 6.72 \\
2006 & 810,508 & 58 & 8.35 & 7.16 \\
2007 & 818,878 & 45 & 6.47 & 5.50 \\
2008 & 830,397 & 57 & 8.20 & 6.86 \\
2009 & 836,951 & 55 & 7.91 & 6.57 \\
2010 & 827,885 & 52 & 7.48 & 6.28 \\
2011 & 832,629 & 55 & 7.91 & 6.61 \\
2012 & 837,217 & 57 & 8.20 & 6.81 \\
Total & $10,472,813$ & 695 & 100.00 & 6.64 \\
\hline
\end{tabular}


The minimum age was 19 years old and the maximum was 98 years old, with a total range of 79 years old and an average age of 56.8 years. Approximately $60 \%$ of deaths happened in women under 60 years old, highlighting the range of 50-59 years old $(21.87 \%)$. There was a statistically significant difference $(p<0.05)$ between the age groups (Table 2$)$.

Table 2 - Deaths from cervical cancer, according to sociodemographic variables

\begin{tabular}{lc}
\hline Variables & $\mathbf{n}(\%)$ \\
\hline Age Group & \\
$15-19$ & $1(0.14)$ \\
$20-29$ & $25(3.60)$ \\
$30-39$ & $79(11.37)$ \\
$40-49$ & $141(20.29)$ \\
$50-59$ & $152(21.87)$ \\
$60-69$ & $125(17.99)$ \\
$70-79$ & $104(14.96)$ \\
80 or + & $67(9.64)$ \\
Ignored & $1(0.14)$ \\
Ethnicity/Color & \\
White & $213(30.64)$ \\
Brown & $370(53.24)$ \\
Black & $66(9.50)$ \\
Yellow & $6(0.86)$ \\
Indian & - \\
Ignored & $40(5.76)$ \\
Marital status & \\
Single & $308(44.32)$ \\
Married & $187(26.91)$ \\
Widowed & $144(20.72)$ \\
Other & $25(3.60)$ \\
Ignored & $31(4.46)$ \\
Occupation & \\
Housewife & $439(63.16)$ \\
Housekeeper & $55(7.91)$ \\
Retired & $24(3.45)$ \\
Businesswoman & $29(4.17)$ \\
Ignored & $37(5.32)$ \\
\hline$\quad$ Other & $111(15.97)$ \\
\hline
\end{tabular}

The nonparametric Chi-square test was performed to compare whether observed frequencies (number of deaths) were different from expected frequencies for the socio-demographic variable "Age Group". The value calculated for statistical test $\chi^{2}$ with 7 degrees of freedom was 661.5. For any level of significance, the value tabulated is lower than the one calculated, i.e., the null hypothesis stating that observed frequencies are not different from expected frequencies is rejected. Therefore, there is a difference between frequencies and so, there is an association between the variables 'Age Group' and 'Ethnicity/Color'. There was a predominance of mixed race/color (53.24\%), single (44.32\%) and housewives (63.16\%) (Table 2).

Table 3 shows that most age groups showed a decrease in mortality rates, except for the age groups 30-39 and 80 and over, which increased by 0.76 and 5.34 respectively, the latter being strongly affected. In the age group up to 19 years old, one death was detected in 2009, whose coefficient was 1.50/100,000 women.

\section{DISCUSSION}

The results of this study show that mortality rates from cervical cancer had a steady decline, with a stable trend. During the period of 2006-2012, 830,565 cervicovaginal cytology tests in the public health system of Recife (PE) were performed, the year 2007 had the highest number of examinations $(136,569)$, and this was the year with the lowest mortality rate $(5.5 \text { per } 100,000)^{(13)}$.

Despite the decrease, the average rate found in the study was higher than that of Brazil ${ }^{(4)}$. There is a consensus in the literature that population screening for cervical cancer is the most important public health strategy because it reduces the incidence and, subsequently, mortality by identifying pre-invasive and invasive lesions in early stages, enabling a more effective treatment ${ }^{(14-15)}$.

Over the past years, screening programs using cervical cytology (Pap smear) have greatly reduced cancer rates in the cervix ${ }^{(9)}$. In Canada, a survey described the relationship among incidence, mortality, and tracking, and showed a decrease in the indicators and that it was probably related to the advancement of cancer detection, which allows early treatment ${ }^{(16)}$.

Table 3 - Mortality rate from cervical cancer, according to age group

\begin{tabular}{cccccccccccccccc}
\hline Age group & $\mathbf{2 0 0 0}$ & $\mathbf{2 0 0 1}$ & $\mathbf{2 0 0 2}$ & $\mathbf{2 0 0 3}$ & $\mathbf{2 0 0 4}$ & $\mathbf{2 0 0 5}$ & $\mathbf{2 0 0 6}$ & $\mathbf{2 0 0 7}$ & $\mathbf{2 0 0 8}$ & $\mathbf{2 0 0 9}$ & $\mathbf{2 0 1 0}$ & $\mathbf{2 0 1 1}$ & $\mathbf{2 0 1 2}$ & $\boldsymbol{\Delta} \%$ \\
\hline $15-19$ & - & - & - & - & - & - & - & - & - & 1.50 & - & - & - & - \\
$20-29$ & 0.72 & 0.00 & 1.41 & 0.70 & 0.69 & 1.36 & 1.35 & 0.66 & 1.99 & 2.66 & 2.05 & 3.39 & - & -100 \\
$30-39$ & 6.56 & 6.50 & 0.12 & 7.19 & 3.96 & 3.11 & 3.85 & 2.27 & 5.17 & 4.36 & 4.46 & 5.91 & 6.61 & 0.76 \\
$40-49$ & 12.60 & 12.48 & 13.41 & 6.14 & 12.17 & 16.92 & 9.86 & 8.81 & 6.04 & 10.22 & 10.10 & 7.53 & 8.32 & -33.96 \\
$50-59$ & 15.75 & 17.15 & 20.11 & 23.01 & 9.13 & 20.90 & 19.23 & 13.50 & 15.39 & 14.94 & 14.19 & 8.68 & 12.95 & -17.77 \\
$60-69$ & 33.75 & 24.51 & 22.10 & 15.34 & 15.21 & 17.07 & 31.70 & 15.56 & 20.64 & 12.72 & 11.91 & 16.91 & 15.14 & -55.14 \\
$70-79$ & 25.38 & 28.72 & 17.80 & 52.97 & 21.01 & 20.63 & 27.25 & 28.71 & 24.84 & 24.30 & 16.71 & 24.91 & 22.03 & -13.19 \\
80 or + & 41.53 & 41.12 & 48.93 & 40.43 & 32.08 & 23.62 & 39.00 & 20.68 & 52.87 & 25.57 & 24.58 & 29.33 & 43.75 & 5.34 \\
\hline
\end{tabular}


A study conducted in Serbia, created a risk index for predicting an abnormal result in Pap smear using the information on the age of first sexual intercourse, multiple partners, STD history and multiparity, to identify women at high risk of cervical cancer who should be submitted to further examination ${ }^{(17)}$.

However, the performance of Pap smear shows great variability among studies ${ }^{(18)}$. The significantly higher sensitivity of HPV testing raises the need for innovation in prevention strategies, with a recommendation for the inclusion of this test ${ }^{(18-19)}$. The presence of the DNA of HPV in the cervix is detected by two efficient methods, i.e., Hybrid Capture II test and polymerase chain reaction (PCR), these tests are used to identify the presence of hazardous HPV viral infections that are associated with the origin of cancer ${ }^{(5)}$.

In Brazil, there is no availability of these tests in the routine of the Brazilian Unified Health System (SUS) due to their cost. Considering the comparison of cervical cytology and its cost with the HPV test, the latter can be used as an auxiliary method in cases with ambiguous diagnosis ${ }^{(20)}$. A study conducted in India proposes a two-step screening model: combining a low-cost highly sensitive test as Acetic acid (VIA) for the primary screening, followed by a more specific DNA of HPV test, as a positive screening. This can be a low-cost cervical screening strategy for countries with limited resources ${ }^{(21)}$.

The HPV vaccine has become a tool used by many countries to prevent cervical cancer and HPV ${ }^{(22)}$. The inclusion of the HPV vaccine in the Brazilian National Immunization Program by the Department of Health was a breakthrough, becoming one of the instruments to control this cancer in Brazil, especially among young women ${ }^{(23)}$.

French scholars, when researching the efficiency of the vaccine against HPV as a prophylactic measure, found that increasing vaccination coverage in the female population, or vaccinating girls before the age of 14 , revealed to have a great impact on the incidence of this cancer ${ }^{(7)}$.

Results showed the majority of deaths occurred among women of mixed race/color, single and housewives. Possibly, socioeconomic factors contribute to a higher occurrence of the disease in this population; these findings come in line with previous studies ${ }^{(11,24-25)}$.

More and more women have been and should be seen as protagonists in prevention actions, while flexible schedules at health facilities allow for their conduction, so as to reduce inequalities in access, thus bringing more participation, regardless of their labor and occupational status ${ }^{(26)}$.

In this study, the age group above 80 years old had the highest mortality rates. In elderly women, the end of the fertile period seems to result in the reduction of gynecological consultations, leading to a break of prevention habits at a time in life in which the severity and incidence of neoplasms are higher $^{(27)}$. The Brazilian Department of Health recommends the first examination at the age of 25 in women who already started sexual activity and should be done until they reach 64 years old and, thereafter, be discontinued when they have two negative tests in the course of five years ${ }^{(24)}$.

National and international research shows a decrease in mortality rates following the implementation of the screening program, nevertheless the positive effects of the program were not seen in elderly women ${ }^{(28-29)}$.

\section{Study limitations}

Limitations of this study are incomplete records, leading to loss of information regarding the epidemiological aspects of cervical cancer deaths.

Contributions to the fields of nursing, health or public policy

This research is of relevance to public health, since it can subsidize government agencies in the planning and development of programs and public policies aimed at reducing mortality, since cancer in the cervix is considered a cause of preventable death when diagnosed early.

\section{CONCLUSION}

Cervical cancer mortality proves to be a key indicator of the living conditions of the population and the standard of care to women's health. Despite the declining tendency of mortality from cervical cancer in Recife, the risk of death is still high, remaining as an important public health problem. The development of educational activities and the introduction of HPV testing as a primary screening tool are recommended to ensure the reduction of incidence and mortality from cervical cancer.

\section{REFERENCES}

1. World Health Organization. WHO. Estimated cancer incidence, mortality and prevalence worldwide in 2012. Globocan [Internet]. 2013[cited 2015 Feb 21]. Available from: http:/www.thehealthwell.info/node/684345

2. Haworth RJ, Margalit R, Ross C, Nepal T, Soliman AS. Knowledge, attitudes, and practices for cervical cancer screening among the Bhutanese refugee community in Omaha, Nebraska. J Community Health [Internet]. 2014[cited 2015 Feb 21];39(5):872-8. Available from: https://www.ncbi.nlm.nih.gov/pmc/articles/PMC4175018/

3. Brasil. Instituto Nacional de Câncer. INCA. Estimativa 2014: Incidência de câncer no Brasil. Rio de Janeiro: Inca; 2014.

4. Brasil. Instituto Nacional de Câncer. INCA. Atlas da Mortalidade, Brasil [Internet]. 2014[cited 2014 Dec 22]. Available from: https://mortalidade.inca.gov.br/MortalidadeWeb

5. Nalliah S, Karikalan B, Kademane K. Multifaceted usage of HPV related tests and products in the management of cervical cancer: a review. Asian Pac J Cancer Prev [Internet]. 2015[cited 2016 Sep 22];16(6):2145-50. Available from: http://journal.waocp.org/ar ticle 30734 6027df658dc425d6dfbacc96e85aa0ad.pdf 
6. Félix A, Alemany L, Tous S, Sanjosé S, Bosch FX. HPV distribution in cervical cancer in Portugal: a retrospective study from 1928 to 2005. Papillomavirus Res [Internet]. 2016 [cited 2017 Feb 23];2:41-5. Available from: https://linkinghub.elsevier.com/retrieve/ pii/S2405-8521(15)30002-1

7. Ribassin-Majed L, Lounes R, Clemencon S. Efficacy of vaccination against HPV infections to prevent cervical cancer in France: present assessment and pathways to improve vaccination policies. PLoS One [Internet]. 2012[cited 2015 May 14];7(3):e32251. Available from: http://www.ncbi.nlm.nih.gov/pmc/articles/PMC3299653/pdf/pone.0032251.pdf

8. Schiffman M, Wentzensen N, Wacholder S, Kinney W, Gage JC, Castle PE. Human papillomavirus testing in the prevention of cervical cancer. J Natl Cancer Inst [Internet]. 2011[cited 2015 May 14];103(5):368-83. Available from: https://www.ncbi.nlm.nih. gov/pmc/articles/PMC3046952/

9. Canadian Task Force on Preventive Health Care. Recommendations on screening for cervical câncer. CMAJ. 2013; 185(1): 35-45.

10. Peirson L, Fitzpatrick-Lewis D, Ciliska D, Warren R. Screening for cervical cancer: a systematic review and meta-analysis. Syst Rev [Internet]. 2013[cited 2015 Jan 18];2:[aprox.14 telas]. Available from: http://www.ncbi.nlm.nih.gov/pmc/articles/PMC3681632/ pdf/2046-4053-2-35.pdf

11. Veloso LC, Silva AC, Silva CLLB. HPV: perception of the carriers in the diagnosis of disease. Rev Interd [Internet]. 2013 [cited 2015 Jan 18];6(4):1-10. Available from: https://revistainterdisciplinar.uninovafapi.edu.br/index.php/revinter/article/download/187/pdf_61

12. Reis GV, Justina GC, Gulnar AS. Disparities in cervical and breast cancer mortality in Brazil. Rev Saúde Pública [Internet]. 2014[cited 2015 Jan 18];48(3):459-67. Available from: http://www.scielo.br/pdf/rsp/v48n3/0034-8910-rsp-48-3-0459.pdf

13. Brasil. Datasus. Siscolo [Internet]. 2015[cited 2015 Jan 15]. Available from: http://tabnet.datasus.gov.br/cgi/tabcgi.exe?siscolo/ ver4/DEF/uf/PECCOLO4.def.

14. Faruk MK, Murat MN. Cervical premalignant lesion and their management. Asian Pac Cancer Prev [Internet]. 2014 [cited 2015 Jan 18];15(5):2245-9. Available from: https://www.ncbi.nlm.nih.gov/pmc/articles/PMC4072548/

15. Sanjosé S, Ibanez R, Rodríguez-Salés V, Peris M, Roura E, Diaz M. et al. Screening of cervical cancer in Catalônia: 20062012. Ecancermedicalscience [Internet]. 2015[cited 2016 Jun 18];9:532. Available from: https://www.ncbi.nlm.nih.gov/ pubmed/25987901

16. Dickinson JA, Stankiewicz A, Popadiuk C, Pogany L, Onysko J, Miller AB. Reduced cervical cancer incidence and mortality in Canada: national data from 1932 to 2006. BMC Public Health [Internet]. 2012[cited 2016 Jun 18];12:992. Available from: https:// www.ncbi.nlm.nih.gov/pmc/articles/PMC3562530/

17. Vukovic D, Antic L, Vasiljevic M, Antic D, Matejic B. Development of a Risk Index for Prediction of Abnormal Pap Test Results in Serbia. Asian Pac J Cancer Prev [Internet]. 2015[cited 2016 Jun 18];16(8):3527-31. Available from: http://journal.waocp.org/ article 30948 b5c8894862c938ce4680e8af651422eb.pdf

18. Terrazas S, Ibáñez C, Lagos M, Poggi H, Branas J, Barriga MI, et al. Human papillomavirus testing in cervical cancer screening at a public health service of Santiago, Chile. Rev Méd Chile [Internet]. 2015[cited 2016 Jun 18];143:56-62. Available from: https:// dx.doi.org/10.1002/ijc.27662

19. Moyer VA, LeFevre ML, Siu AL, Bibbins-Domingo K, Curry SJ, Ebell M. Screening for cervical cancer: U.S. Preventive Services Task Force recommendation statement. Ann Intern Med [Internet]. 2012[cited 2016 Jun 18];15(2):120-34. Available from: https:// www.ncbi.nlm.nih.gov/pubmed/22711081

20. Othman N, Othman NH. Detection of human papillomavirus DNA in routine cervical scraping samples: use for a national cervical cancer screening program in a developing nation. Asian Pac Cancer Prev [Internet]. 2014[cited 2016 Jun 18];15(5):22459. Available from: https://www.ncbi.nlm.nih.gov/pubmed/24716964

21. Pimple S, Shastri SS. Comparative evaluation of human papilloma virus-DNA test verses colposcopy as secondary cervical cancer screening test triage screen positive women inspection with 5\% Acetic acid. Indian J Cancer [Internet]. 2014 [cited 2016 Jun 18];51(2):117-23. Available from: http://dx.doi.org/10.4103/0019-509X.138165

22. Kok IM, Rosmalen J, Rozemeijer K, Penning C, Ballgooijen M. How many cervical cancer cases can potentially be prevented using a more sensitive screening test at young age? Int J Cancer [Internet]. 2014[cited 2016 Jun 18];134(2):460-6. Available from: https:// dx.doi.org/10.1002/ijc.28366

23. Silva DSM, Silva AMN, Brito LMO, Gomes SRL, Nascimento MDSB, Chein MBC. Cervical cancer screening in the State of Maranhão, Brazil. Ciênc Saúde Colet [Internet]. 2014[cited 2016 Jun 18];19(4):1163-70. Available from: http://www.scielo.br/pdf/ csc/v19n4/1413-8123-csc-19-04-01163.pdf

24. Thuler LCS, Bergmann A, Casado L. Profile of the Patients with Cervical Cancer in Brazil, 2000-2009: secondary base study. Rev Bras Cancerol [Internet]. 2012[cited 2016 Jun 18];58(3):351-7. Available from: http://www1.inca.gov.br/rbc/n_58/v03/pdf/04_ artigo_perfil_pacientes_cancer_colo_utero_brasil_2000_2009_estudo_base_secundaria.pdf

25. Batista, RPB, Mastroeni, MF. Factors associated with poor adherence to colpocytological examination in adolescent mothers. Acta Paul Enferm[Internet]. 2012[cited 2016 Jun 18];25(6):879-88. Available from: http://www.scielo.br/pdf/ape/v25n6/en_v25n6a09.pdf

26. Brischiliari SCR, Dell'Agnolo CM, Gil LM, Romeiro TC, Gravena AAF, Carvalho MDB, et al. Factors associated with lack of Pap smear screening in a group of postmenopausal Brazilian women. Cad Saúde Pública [Internet]. 2012 [cited 2016 Jun 18];28(10):1976-84. Available from: http://www.scielo.br/pdf/csp/v28n10/15.pdf 
27. Borges MF, Dotto LM, Koifman RJ, Cunha MA, Muniz PT. Prevalence of uterine cervical cancer testing in Rio Branco, Acre State, Brazil, and factors associated with non-participation in screening. Cad Saúde Pública [Internet]. 2012 [cited 2016 Jun 18];28(6):1156-66. Available from: http://www.scielo.br/pdf/csp/v28n6/14.pdf

28. Almeida FM, Oliveira JC, Martins E, Curado MP, Freitas R, Moreira MAR. Monitoring the profile of cervical cancer in a developing city. BMC Public Health [Internet]. 2013[cited 2016 Jun 18];13:563. Available from: https://www.ncbi.nlm.nih.gov/pmc/articles/ PMC3691764/

29. Lee NC, Wong FL, Jamison PM, Jones SF, Galaska L, Brady KT, et al. Implementation of the National Breast and Cervical Cancer Early Detection Program: the beginning. Cancer [Internet]. 2014[cited 2016 Jun 18];120(16-Suppl):2540-8. Available from: https:// www.ncbi.nlm.nih.gov/pmc/articles/pmid/25099896/ 